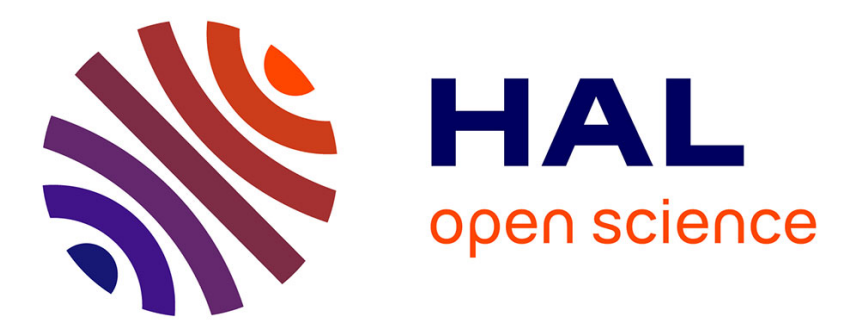

\title{
Studies in Neotropical Araliaceae. Three new species of Sciodaphyllum P. Browne (Araliaceae) with globose capitate inflorescences from Ecuador and Peru
}

Carlos Rodrigues-Vaz, Gregory Plunkett, Porter Lowry Ii

\section{- To cite this version:}

Carlos Rodrigues-Vaz, Gregory Plunkett, Porter Lowry Ii. Studies in Neotropical Araliaceae. Three new species of Sciodaphyllum P. Browne (Araliaceae) with globose capitate inflorescences from Ecuador and Peru. Brittonia, Springer Verlag, 2021, 73 (3), pp.262-273. 10.1007/s12228-021-09661-0 . hal-03439405

\section{HAL Id: hal-03439405 \\ https: / hal.sorbonne-universite.fr/hal-03439405}

Submitted on 25 Nov 2021

HAL is a multi-disciplinary open access archive for the deposit and dissemination of scientific research documents, whether they are published or not. The documents may come from teaching and research institutions in France or abroad, or from public or private research centers.
L'archive ouverte pluridisciplinaire HAL, est destinée au dépôt et à la diffusion de documents scientifiques de niveau recherche, publiés ou non, émanant des établissements d'enseignement et de recherche français ou étrangers, des laboratoires publics ou privés. 


\title{
Studies in Neotropical Araliaceae. Three new species of Sciodaphyllum P. Browne (Araliaceae) with globose capitate inflorescences from Ecuador and Peru
}

\author{
Carlos Rodrigues-Vaz ${ }^{1,2,3,4}$, Gregory M. Plunkett ${ }^{1,2}$, and Porter P. Lowry II ${ }^{3,5}$ \\ ${ }^{1}$ Cullman Program for Molecular Systematics, New York Botanical Garden, 2900 Southern Blvd., Bronx, \\ New York, NY 10458-5126, USA; e-mail: carlos.rodrigues.vaz@gmail.com \\ ${ }^{2}$ Biology Department, The City University of New York, The Graduate Center, 365 5th Ave., New York \\ City, USA \\ ${ }^{3}$ Institut de Systématique, Évolution, et Biodiversité (ISYEB), Institut de Systématique, Évolution, et \\ Biodiversité (ISYEB), Muséum National d'Histoire Naturelle, Centre National de la Recherche \\ Scientifique, Sorbonne Université, École Pratique des Hautes Études, Université des Antilles, C.P. 39, 57 \\ rue Cuvier, 75005, Paris, France \\ ${ }^{4}$ IRD, DIADE, University of Montpellier, Montpellier, France \\ ${ }^{5}$ Missouri Botanical Garden, 4344 Shaw Blvd., St. Louis, MO 63166-0299, USA
}

\begin{abstract}
In the genus Sciodaphyllum (Araliaceae), some species have paniculate inflorescences with globose capitula as their terminal units, in which numerous tightly packed flowers develop into fruits that are appressed to each other. This informal assemblage, referred to as the "globose-capitate group," currently includes 20 described species. Three new species with this distinctive morphology are described and illustrated with photographs of plants in the field or scans of herbarium specimens: $\boldsymbol{S}$. basiorevolutum from northern Ecuador at the border of Carchi and Sucumbíos provinces; $\boldsymbol{S}$. chachapoyense from the department of Amazonas, Peru, known only from the province of Chachapoyas; and $\boldsymbol{S}$. rufilanceolatum from the province of Carchi, Ecuador, north of Maldonado along the border with Colombia, and in the Cerro Golondrinas. For each new species, a distribution map and a preliminary risk of extinction assessment (following the IUCN Red List criteria) are provided; $S$. basiorevolutum is assessed as Vulnerable, whereas $S$. chachapoyense and S. rufilanceolatum are both considered to be Endangered.
\end{abstract}

Keywords: Schefflera, Neotropics, Sciodaphyllum basiorevolutum, Sciodaphyllum chachapoyense, Sciodaphyllum rufilanceolatum, Sciodaphyllum rufilanceolatum.

As circumscribed during the last half century, Schefflera was not only the largest member of Araliaceae in the Neotropics, but also globally, with 605 accepted species (Frodin \& Govaerts, 2003) and several hundred more awaiting formal description (Frodin et al., 2010, Plunkett et al., 2018). Phylogenetic studies of Araliaceae based on molecular data, however, demonstrated that Schefflera is polyphyletic (Plunkett et al., 2005; see also Plunkett et al., 2004a, b), comprising five well supported and geographically structured clades, none of which are sister groups. The smallest of these clades, Schefflera sensu stricto, contains the generic type, necessitating the taxonomic transfer of all species belonging to the other four clades. The "Neotropical Schefflera" clade, the second largest of them, has an estimated total of ca. 400 described and undescribed species occurring primarily in three centers of diversity, Central America, the Guiana Shield, and the Andean Cordillera (Fiaschi \& Plunkett, 2011; Frodin, 1995; Frodin \& Govaerts, 2003; Plunkett et al., 2005, 2019). 
Studies of Neotropical Schefflera by Fiaschi and Plunkett (2011) and Plunkett et al. (2019) confirmed that the group is monophyletic and clarified phylogenetic relationships among its major lineages. In the study of Plunkett et al. (2019), 211 samples representing nearly 140 species were used along with 38 samples from 22 other genera of Araliaceae, from which six spacer regions were sequenced, including two nuclear (ETS, ITS) and four plastid markers (rpl32-trnL, trnF-rpl32, trnK-rpl16, psbA-trnH). The results confirmed the earlier findings of Fiaschi and Plunkett (2011) based on more limited sampling, in particular that the Neotropical clade comprises five major lineages, four of which overlapped significantly with groups informally recognized as Cephalopanax, Crepinella, Didymopanax, and Sciodaphyllum (Frodin et al., 2010; Plunkett et al. 2005, 2019), to which a small fifth clade was added, comprising just two species, informally referred to as Gleasonia.

Given that all species in the Neotropical clade must be transferred out of Schefflera, a decision was made to recognize five genera, each corresponding to one of the groups identified in earlier studies (see Lowry et al., 2019a). As a consequence, the generic name Sciodaphyllum P. Browne was resurrected to accommodate the 131 currently recognized species belonging to that group (Lowry et al., 2019a), and the names Crepinella Marchal and Didymopanax Decne. \& Planch. were likewise resurrected for the 33 and 37 species they contain, respectively (Lowry et al., 2019b; Fiaschi et al., 2020). The two remaining groups, both of which are very small (comprising three and two described species, respectively) are being named as new genera.

Sciodaphyllum is geographically widespread, but most of its species occur in southern Central America (Costa Rica and Panama) and in the northern and central Andes, ranging from Venezuela to Bolivia, with outliers in the Antilles and the Guiana Shield. The genus is morphologically diverse and thus rather difficult to characterize, but all of its species have united petals that form a calyptrate corolla abscising as a unit at anthesis. Additionally, many but not all species have a (hemi-)epiphytic habit and leaves with large ligulate stipules.

Many species of Sciodaphyllum have paniculate or compound-umbellate inflorescences in which the flowers are ultimately arranged in umbellules, but most of the species have other types of ultimate inflorescence units, including heads, racemules, or spicules (Frodin \& Govaerts, 2003; Plunkett et al., 2019). Of those species with flowers arranged in spherical to ovoid heads, the shape, size, and arrangement of these structures vary. These heads may be divided into two types, which we refer to as globose capitate and non-globose capitate. While a continuum exists between the extremes of these two morphologies, and while some species have heads that are intermediate in size, most capitate species of Sciodaphyllum can readily be assigned to one of these two types. Globose heads are usually large (at least 2 to $5 \mathrm{~cm}$ in diameter in fruit) and contain numerous, tightly packed flowers maturing into fruits that are obpyramidal in shape and tightly appressed to one another. Non-globose heads are smaller (generally no more than $2 \mathrm{~cm}$ in diameter in fruit) and contain substantially fewer flowers developing into fruits that are terete in cross-section and are not closely appressed to one another at maturity. This variation in inflorescence appearance and fruit shape appears to be due to the tight packing of flowers in the globose capitate species, which restricts the growth of the basal portion of each fruit but allows expansion of its apex.

To improve our knowledge of the globosecapitate species of Sciodaphyllum, collections from 14 major herbaria where studied (AAU, CPUN, CUZ, ECUAMZ, F, HOXA, LOJA, MO, NY, P, QCA, QCNE, US, USM) and carefully compared to the available type specimens (including photos) and protologues of described species. This process revealed numerous clearly distinct taxa that did not appear to correspond to any validly published names. The analysis of specimens and their comparison with type material was, however, complicated by the fact that collections of Sciodaphyllum are often fragmentary and poorly prepared, lacking key diagnostic characters needed for accurate identification. For example, the inflorescences are sometimes so large that it is impossible to include them in their entirety on a single herbarium sheet. As a consequence, many specimens contain only a small portion of the inflorescence, sometimes only a single axis from a highly branched structure, and thus lack critical information about its overall size and organization. The situation is further complicated by changes in inflorescence structure that occur during development. For example, in early stages, flower buds may be densely arranged in 
what appear to be capitula, but as they mature, the pedicels may form and elongate, resulting in an umbellate arrangement. It is, therefore, important to obtain material from as many developmental stages as possible in order to make an informed decision regarding inflorescence types. A similar situation is encountered with leaf structure and development. In many species, the petiole base is frequently not collected, despite the fact that the shape and size of their ligulate stipules are often essential for accurate identification. Moreover, leaves often undergo significant changes as they mature. For example, the young leaves of some species are thin and covered with dense ferruginous indument, but as they mature, they thicken and lose most of their trichomes. In such cases, having a developmental series is necessary to associate the various stages of leaf development.

In order to obtain material representing as many developmental stages of globose capitate species of Sciodaphyllum as possible, targeted field work was conducted in Ecuador and Peru, where most of the apparently new species where identified. Results of the combined herbarium and field work suggest that the globose-capitate morphology characterizes 20 currently named and accepted species as well as more than 70 potentially new species, of which 26 are clearly circumscribed and ready to be described, along with about 45 additional novelties that will require more in-depth studies to determine their taxonomic status. Members of this group range from small treelets to larger trees (up to 15 to 20 $\mathrm{m}$ tall) and they typically occur at high elevations (2000 to $3500 \mathrm{~m}$ ) in primary or partially disturbed cloud or dwarf forests, and occasionally as pioneer species in disturbed forests. Some species, however, occur at lower elevations, such as S. pentandrum (Pav.) Harms, which grows from 800 to $2000 \mathrm{~m}$. Globose capitate species are exclusively found in the northern and central Andes, extending from southern Colombia to Bolivia.

As an initial step toward advancing our understanding of the globose capitate members of Sciodaphyllum, three new species initially identified based on herbarium collections, two of which were subsequently collected in the field, are described here. This work complements several other papers in which new non-globose capitate species of Sciodaphyllum are being described, including three from the eastern slopes of the Peruvian Andes (Mora et al., 2020a) and one with small heads from Antioquia in Colombia (Mora et al., 2020b).
For each of the three new species described here, a distribution map was prepared and a preliminary risk of extinction assessment was performed, following the IUCN Red List criteria (IUCN, 2012; IUCN Standards and Petitions Committee, 2019). To determine geographic coordinates of older collections for which longitude and latitude data were not available, an estimate was made post-facto using locality information from specimen labels along with maps and online resources such as Google Earth (these are indicated in square brackets).

Sciodaphyllum basiorevolutum RodriguesVaz, G. M. Plunkett, \& Lowry, sp. nov. Type: Ecuador, Carchi Province: Cantón Huaca, on the road from Mariscal Sucre (Colonia Huaqueña) to the "Estación Biológica-Guandera", just beyond the entrance to the station, remnant forest, $0^{\circ} 35^{\prime}$ $12.4^{\prime}{ }^{\prime} \mathrm{N}, 77^{\circ} 42^{\prime} 35.99^{\prime \prime} \mathrm{W}, 3348 \mathrm{~m}, 19$ Oct 2016 [immature infl, b, fl, fr], Rodrigues-Vaz \& Rosillo 152 (holotype: ECUAMZ [3 sheets: ECUAMZ00065, ECUAMZ-00066, ECUAMZ-00067]!; isotypes: MO!, NY!, QCNE!).

(Fig. 1)

Diagnosis: Sciodaphyllum basiorevolutum can be distinguished from all other globose capitate members of the genus in Ecuador by a combination of two characters, leaflets whose margins are strongly revolute only at the base and reddishbrown pubescent indument comprising branched and shaggy trichomes found throughout, except for the glabrescent adaxial surface of the leaves.

Unbranched or branched treelet or tree, 418 , tall. Leaves palmately compound, spirally arranged, 36.3-72.4 cm long, with lenticels on petiole base, ligulate stipule, and stem; stipule triangular, 4.6-6.2 × 4.2-5.2 cm, fleshy adaxially, covered with grayish-white pubescent indument comprising dendritic trichomes, glabrescent, margin entire, often scarious, up to $7.9 \mathrm{~mm}$ wide, green to purple, drying darkreddish brown to black; petiole $19.9-39.5 \mathrm{~cm}$ long, 4.6-8.4 mm diam., covered with reddishbrown pubescent indument comprising branched and shaggy trichomes; leaflets 9-13, borne in a single whorl, petiolules $1.8-6.7 \mathrm{~cm}$, compressed laterally, sulcate adaxially, blade lanceolate to elliptic or oblong, conduplicate, dark green adaxially, pale green abaxially (in vivo), olive green to dark brown above, lighter below (in sicco), coriaceous, 14.6-26.2 $\times 4.1-10 \mathrm{~cm}$, covered with reddish-brown pubescent indument of branched, shaggy 

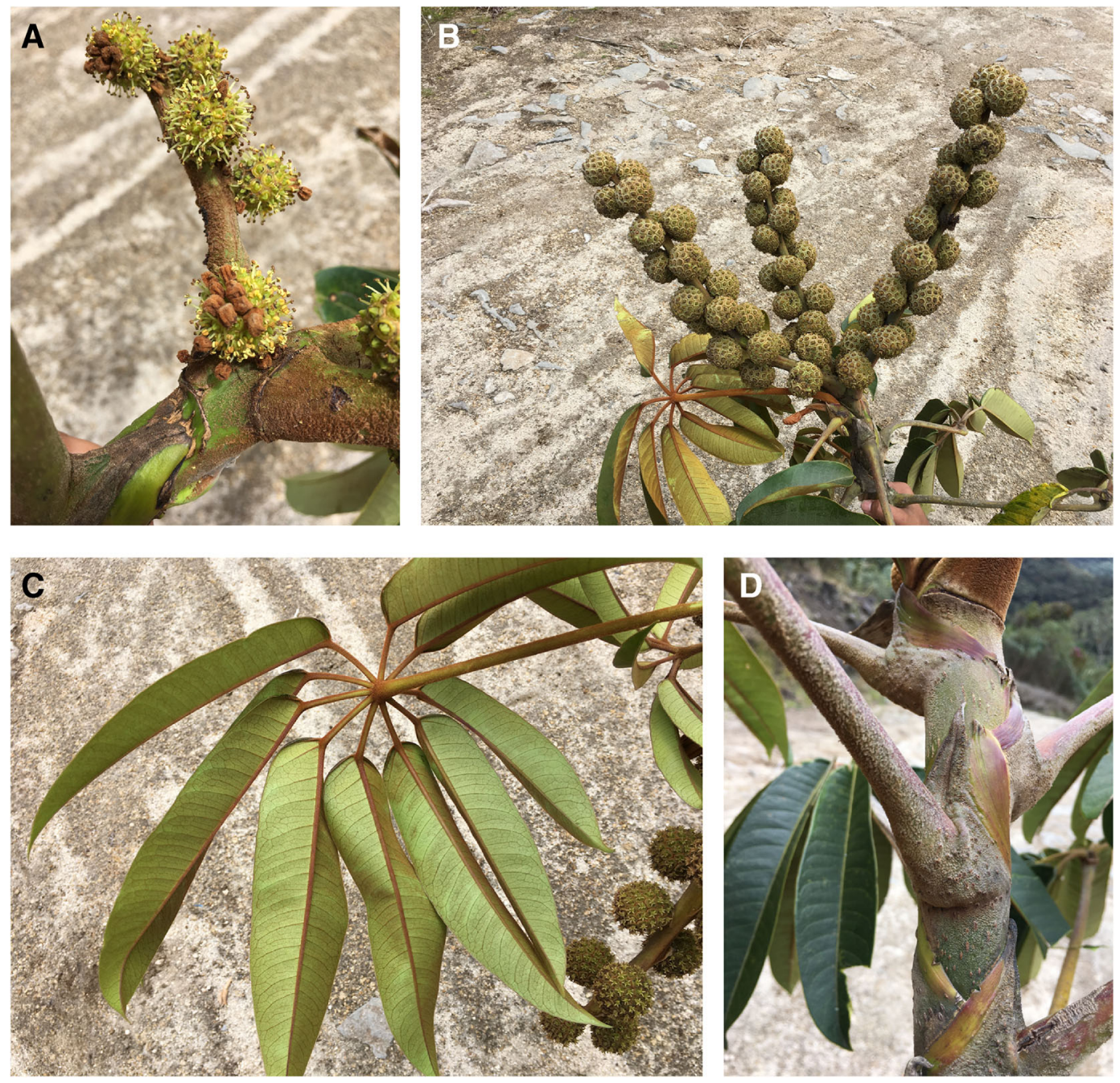

Fig. 1. Sciodaphyllum basiorevolutum A. Heads in flower showing calyptrate corollas covered with reddish-brown pubescent indument. B. Infructescence of large globose heads. C. Leaflets showing strongly revolute margins at the base. D. Ligulate stipules with green to purple scarious margins.

trichomes when young, adaxial surface glabrescent in mature leaflets, indument persistent on abaxial surface, base obtuse to rounded or truncate, margin entire, strongly revolute toward the base (the fold up to $5 \mathrm{~mm}$ wide), apex acuminate to attenuate, venation pinnate, primary vein prominent, slightly raised and yellowish-green adaxially, strongly raised abaxially, secondary veins $17-26$ on each side, visible to obscure adaxially, raised abaxially, tertiary veins obscure adaxially, visible abaxially, inter-secondary veins present, proximal $2-5$ secondary veins originating together from the base of the midvein, collecting vein present, $1.8-5.6 \mathrm{~mm}$ from margin. Inflorescence pseudo-lateral (resulting from delayed development of an initially terminal inflorescence), erect to ascending, paniculate, with three orders of branching, bracts caducous, triangular, 3.8-9.6 × 4.1-7.5 mm, scar narrow, crescent-shaped; primary axis $2.6-3.5 \mathrm{~cm}$ long (to ca. $8 \mathrm{~cm}$ in fruit); secondary axes $2-5,19.4-$ $42.4 \mathrm{~cm}$ long, $1.3-1.5 \mathrm{~cm}$ diam. at the base; ultimate units heads, spherical to ellipsoid, covered with reddish-brown pubescent indument comprising dendritic trichomes, 
$1.0-2.8 \mathrm{~cm}$ diam. in bud, expanding to $2.2-$ $3.6 \mathrm{~cm}$ diam. in fruit, sessile to pedunculate, peduncle, when present, to $1.3 \mathrm{~cm}$ long, $0.5-$ $1.1 \mathrm{~cm}$ diam. Flowers hermaphroditic, 65-122 per head, closely appressed to one another; calyx a barely visible, low, undulate $\mathrm{rim} /$ crown with obscure lobes, at most $0.1 \mathrm{~mm}$ high, $2.9-4.8 \mathrm{~mm}$ wide, calyx rim and disc pale green turning pinkish-red at maturity; corolla calyptrate, narrowly to broadly cylindrical with a rounded to flat top, covered with reddish-brown pubescent indument; petals $6,3.2-5.8 \times 2.5-5.9 \mathrm{~mm}$; stamens 5 or 6 , in a single series, filaments $2-3.1 \mathrm{~mm}$ long at pollen presentation, anthers brownish becoming creamy yellow at pollen presentation, 1$1.5 \mathrm{~mm}$ long; ovary 5- or 6- (or 7)-carpellate, brownish sometimes tinged pink, drying black; styles 5 or 6 (or 7), appressed before receptivity, spreading at maturity, pale green, drying black, 1.6-3.4 mm long, united to half their length. Fruits pale green turning pale yellow, fleshy, obpyramidal, transversely pentagonal or hexagonal (rarely heptagonal), closely appressed to one another, $7.2-12.8 \times 4.2-6.2$ $\mathrm{mm}$, base truncate to conical, with 5 or 6 (or 7) ribs when dry (as many as carpels).

Distribution and habitat.-Sciodaphyllum basiorevolutum is known from the border area between the provinces of Carchi and Sucumbíos in northern Ecuador, in the area around the Contrafuerte del Mirador, at elevations of 2350$3500 \mathrm{~m}$, in primary to disturbed forests (Fig. 2).

Etymology.-The species name refers to the main diagnostic character of this species, its strongly revolute margins at the base of the leaflets.

Conservation status.-Sciodaphyllum basiorevolutum has been collected at ten localities corresponding to five subpopulations. Its geographic range has an EOO of $340.1 \mathrm{~km}^{2}$ and an AOO of $56 \mathrm{~km}^{2}$. The species is present in one protected area, the Estación Biológica Guandera, but outside this area it is threatened by forest clearing for agriculture that involves patches ranging in size from a few $\mathrm{km}^{2}$ to $100 \mathrm{~km}^{2}$, resulting in projected continuing decline of EOO, AOO, quality of habitat, number of locations and subpopulations, and number of mature individuals. With regard to the primary threat of deforestation, $S$. basiorevolutum is present at 11 locations and is therefore assessed as Near Threatened [NT] using the IUCN Red
List Categories and Criteria (IUCN, 2012; IUCN Standards and Petitions Committee, 2019), since it nearly qualifies for Vulnerable status under criteria B1 and B2.

Additional specimens examined. ECUADOR. Carchi: Carretera Julio Andrade-El Carmen km 18, [00³9'10'N, 77³6'50”W], 3200 m, 16 May 1982 [fr], Balslev 2535 (AAU [2 sheets], NY [2 sheets]); road from Julio Andrade to El Carmelo in the pass on the old road above El Playón de San

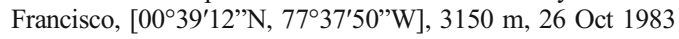
[fl], Balslev 4455 (AAU); Parroquia Huaca, Bosque Protector

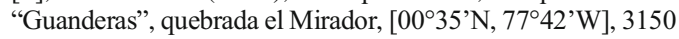
m, 18-19 Mar 1995 [fr], Cerón 28,433 (MO [2 sheets]); $17.5 \mathrm{~km}$ E of Santa Bárbara along road from Tulcán to Alegría via Caramelo and Santa Bárbara, [00³5'10”N, 77³0'46”W], 2600 m, 5 Feb 1982 [fr], Dodson 12,129 (QCNE, MO, US); $12.7 \mathrm{~km} \mathrm{E}$ of La Estrellita on road to El Carmelo, [00 $41^{\prime} 52^{\prime \prime} \mathrm{N}$, 77³9'22”W], 16 Nov 1988 [fr], Dorr 6155 (QCNE, NY); Mirador, ca. $12 \mathrm{~km} \mathrm{~N}$ of El Playón de San Francisco, [00³7'N, 77³7'W], 3300-3500 m, 27 Nov 1983 [fr], Eriksen 45,795 (AAU); SE of El Playón de San Francisco on the slopes of Cerro Mirador, $\left[00^{\circ} 35^{\prime} \mathrm{N}, 77^{\circ} 38^{\prime} \mathrm{W}\right], 3300-3700 \mathrm{~m}, 28$ Dec 1980 [st], Holm-Nielsen 29,866 (AAU); Julio-AndradeEl Carmelo, turn off towards El Ajún, km 0-3, [00³9’ N, 77³8'W], 3050-3100 m, 10 Aug 1990 [fl], Jørgensen 92,361 (AAU [2 sheets]); al este de la Colonia Huaqueña, en el sector Bretaña o Loma Corazón, [00³8'N, $77^{\circ} 41^{\prime} \mathrm{W}$ ], 3000-3200 m, 18 Feb 1989 [b, fr], Palacios 3909 (QCNE [2 sheets], MO [2 sheets]); ibid. loc., [00³6'N, 7742'W], 32003450 m, 20 Feb 1989 [b, fl], Palacios 3932 (QCNE [2 sheets], MO [3 sheets]); Montufar Cantón, Lomo El Corazón (Bretaña), al sureste de Huaca, al este de la Colonia Huaqueña, Río Minas, [00³6’N, 7742’W], 3200 m, 4 Apr 1991 [b], Palacios 6968 (QCNE, MO); on the road from Mariscal Sucre (Colonia Huaqueña) to the "Estación Biológica Guandera", a little before arriving at the sign indicating the entrance to the station, $00^{\circ} 35^{\prime} 12^{\prime}$ 'N , 7742'36”W, $3348 \mathrm{~m}, 19$ Oct 2016 [immature fr], Rodrigues-Vaz 153 (ECUAMZ [2 sheets: ECUAMZ-00178, ECUAMZ-00179], NY); road from Julio Andrade to El Carmelo, turn-off towards El Ajún, a few km after El Ajún, at edge of a recently cut forest, probably used for grazing pastures, not far from river, $0^{\circ} 40^{\prime} 28.29^{\prime \prime} \mathrm{N}, 7^{\circ} 37^{\prime} 43.91^{\prime \prime} \mathrm{W}$, 3239 m, 19 Oct 2016 [b, fr], Rodrigues-Vaz 154 (ECUAMZ [2 sheets: ECUAMZ-00180, ECUAMZ-00181], NY); road from Julio Andrade to El Carmelo, turn-off towards El Ajún, along road a few km after El Ajún, 0040'28.29”N, $77^{\circ} 37^{\prime}$ 43.91" W, 3239 m, 19 Oct 2016 [immature fr], Rodrigues-Vaz. 155 (ECUAMZ [2 sheets: ECUAMZ-00182, ECUAMZ00183], NY); Montufar Cantón, Lomo El Corazón (Bretaña), al sureste de Huaca, al este de la Colonia Huaqueña, Río Minas, [00³5'N, 7742'W], 3200-3500 m, 26 Mar 1989 [b, fl], Tipaz 8 (QCA, QCNE, MO [2 sheets]); ibid. loc., 2 Jul 1989 [fr], Tipaz 96 (QCNE [2 sheets], MO). Succumbios: Road Playón de San Francisco-La Bonita, km 28, past Santa Bárbara, [00³5’ N, 77³0’W], 2690 m, 5 May 1993 [b, fl, immature fr], Borchsenius 81 (AAU [3 sheets]); Parroquia El Playón de San Francisco, base del Cerro Mirador, sector la Pradea, quebrada Cuscungo, [00³7'36”N, 77³7'27’W], 3000-3100 m, 5 Aug 1996 [fr], Cerón 31,976 (MO); carretera Playón de San Francisco-La Bonita, [00³7'36”N, 77³7'27’W], 28003000 m, 27 Dec 1986 [b, fr], Josse 104 (NY); Parroquia La 


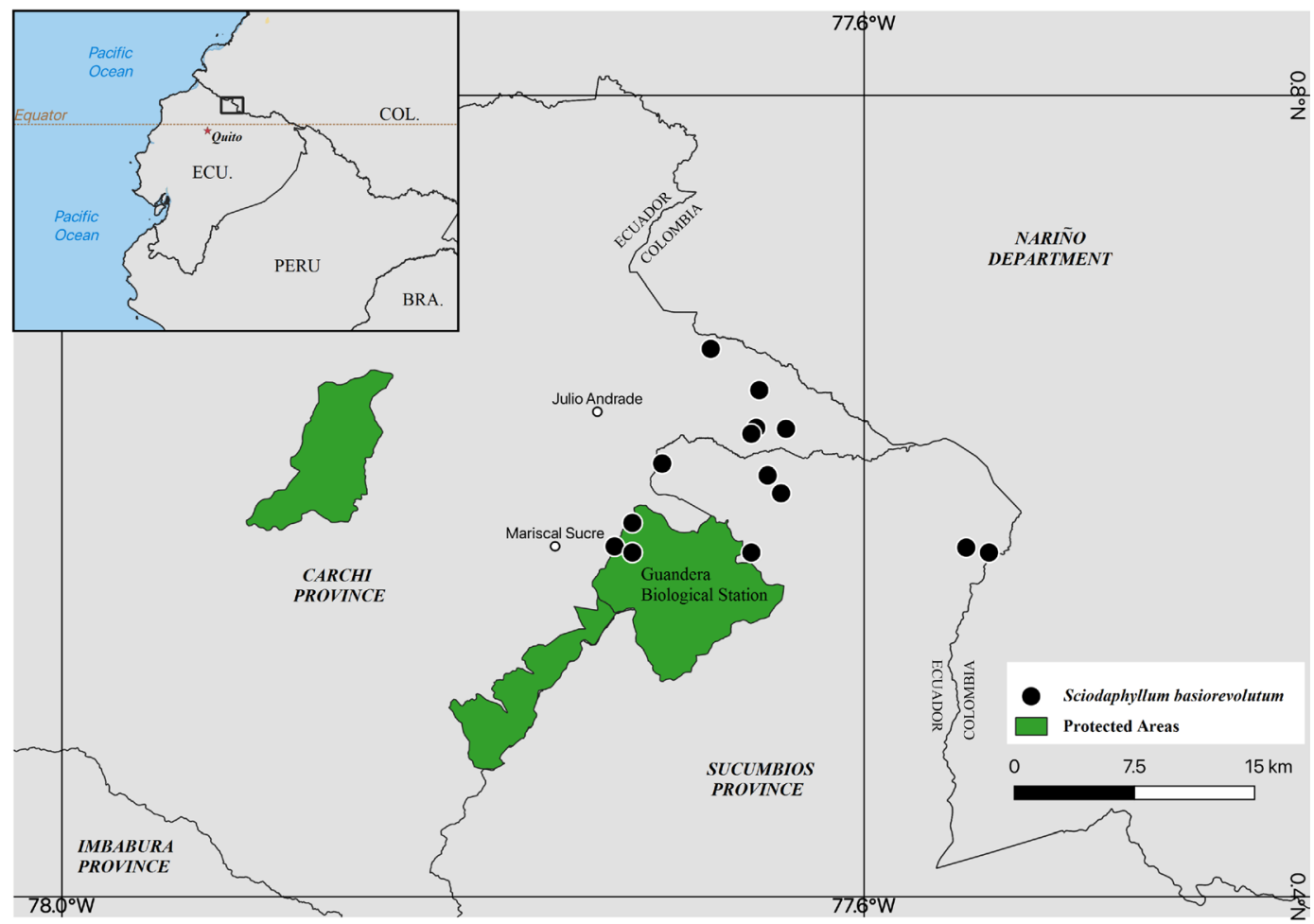

FIG. 2. Geographic distribution of Sciodaphyllum basiorevolutum.

Bonita, ca. $80 \mathrm{~km}$ de la vía Tulcán-La Agrio, sector Valle

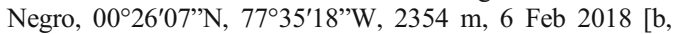
fr], Mora 1120 (ECUAMZ, MO, NY).

Sciodaphyllum chachapoyense RodriguesVaz, G. M. Plunkett, \& Lowry, sp. nov. Type: Peru, Amazonas: Province Chachapoyas, along road from Leymebamba to Balsas, km 410409 , dwarf forest, $06^{\circ} 43^{\prime} 16.26^{\prime \prime} \mathrm{S}, 77^{\circ} 50^{\prime}$ 42.22'W, 2975 m, 10 Oct 2016 [fl, fr], Rodrigues-Vaz \& Cueva 148 (holotype: USM (mounted on several sheets)!; isotypes: MO!, NY [3 sheets: 03109069, 03109070 , 03109071]!).

(Fig. 3)

Diagnosis: Sciodaphyllum chachapoyense closely resembles $S$. mathewsii Seem. in being a treelet with paniculately arranged heads and similarly shaped coriaceous, conduplicate leaflets, but differs in having larger globose heads of ca. 62-94 flowers (vs. smaller non-globose heads with 10-40 flowers) and larger leaves (32.7-52.5 cm vs. $10.4-33 \mathrm{~cm}$ long).

Unbranched to branched treelet, 1-7 $\mathrm{m}$ tall. Leaves palmately compound, spirally arranged, $32.7-52.5 \mathrm{~cm}$ long, with lenticels on petiole base, ligulate stipule, and stem; stipule triangular, 2.6$4.5 \times 2.3-4.2 \mathrm{~cm}$, with silvery-white floccose to lanate indument comprising branched trichomes, the margin entire; petiole $15-22.5 \mathrm{~cm}$ long, 4.1$6.3 \mathrm{~mm}$ diam., glabrous; leaflets $8-10$, borne in a single whorl, petiolule $1-4.5 \mathrm{~cm}$, blade oblong to obovate-oblong, conduplicate, dark green adaxially, pale green abaxially (in vivo), olive green to brown above and below (in sicco), coriaceous, 9-21.7 × 3.3-7.5 cm, densely covered with ferruginous indument when young, glabrescent, base rounded to cordate, margins entire, sometimes minutely revolute, apex acuminate, venation pinnate, primary vein prominent, slightly raised adaxially, raised abaxially, secondary veins $21-$ 52 on each side, obscure adaxially, visible abaxially, tertiary veins obscure adaxially, visible abaxially, inter-secondary veins present, collecting vein present, $0.4-2.1 \mathrm{~mm}$ from margin. Inflorescence pseudo-lateral (resulting from delayed development of an initially terminal inflorescence), erect to ascending, paniculate, with three orders of branching, bracts caducous, triangular, 4.7-9.8 $\times$ 2.8-6.2 mm, scar thin, crescent-shaped; primary 

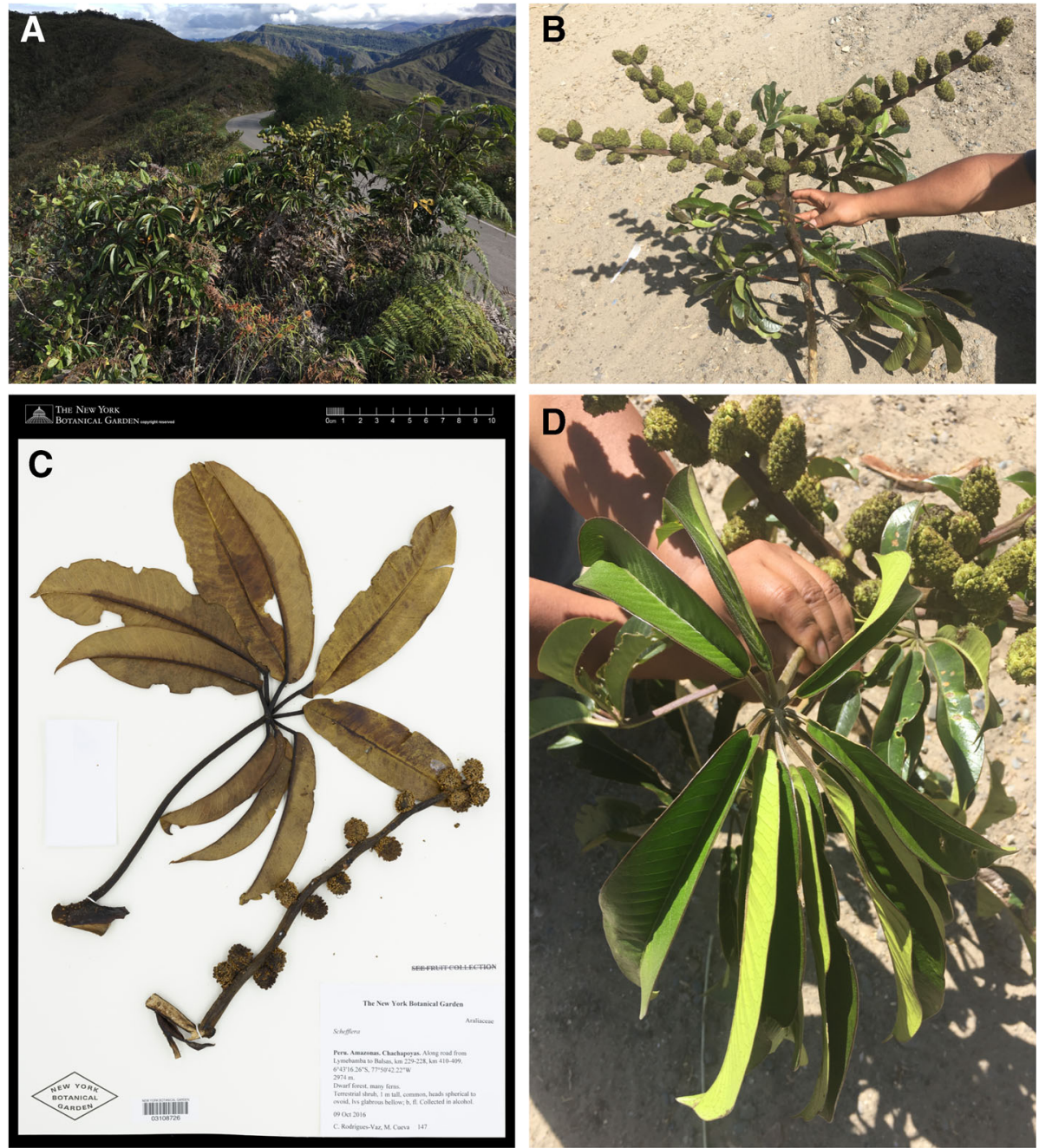

Fig. 3. Sciodaphyllum chachapoyense. A. Branched treelet growing in fern-dominated (Pteridium arachnoideum) open and disturbed area. B. Infructescence of large globose heads. C. Specimen in bud and flower, Rodrigues-Vaz 147 [NY03108726]. D. Leaf showing conduplicate leaflets.

axis $3.6-11.1 \mathrm{~cm}$ long; secondary axes 2 or 3, 21.5-31 cm long; ultimate units heads, spherical to ovoid or ellipsoid, $1.1-1.6 \mathrm{~cm}$ diam. in bud, expanding to $1.5-3.5 \mathrm{~cm}$ diam. in fruit, sessile to pedunculate, peduncle, when present, up to $9.3 \mathrm{~mm}$ long, 3.3-5.1 mm diam. Flowers hermaphroditic, 62-94 per head, closely appressed to one another; calyx a low undulate rim/crown, up to $0.4 \mathrm{~mm}$ high, $2.8-4.4 \mathrm{~mm}$ wide; corolla calyptrate, pale green (sometimes tinged with red), turning brownish when dry, with silverywhite floccose to lanate indument comprising branched trichomes, broadly cylindrical, with a rounded to flat top, drying bullate/verrucose, 3.6$4.4 \times 1.7-2.6 \mathrm{~mm}$; stamens $5-8$, in a single series, filaments $0.9-1.3$ long when calyptra is first shed, expanding to $2.1-3.4 \mathrm{~mm}$ long at pollen presentation, anthers tan-yellow, 1-1.5 mm long; ovary 46-carpellate, pale green; styles 4-6, free, forming short, stout nubs, appressed before receptivity, spreading at maturity, $0.8-1.8 \mathrm{~mm}$ long. Fruits green, fleshy, obpyramidal, transversely square, pentagonal or hexagonal (depending on the number of carpels), closely appressed to one another, $6.5-10.3 \times 2.5-4.5 \mathrm{~mm}$, base truncate to conical, with 4-6 ribs when dry (as many as the carpels). 
Distribution and habitat.-Sciodaphyllum chachapoyense is known only from ferndominated (Pteridium arachnoideum), open and disturbed area in Chachapoyas Province in Amazonas Department, northern Peru, at elevations of ca. 2700-3250 m (Fig. 4).

Etymology.-The name Sciodaphyllum chachapoyense was chosen because this species is known only from Chachapoyas Province in Peru.

Conservation status. - Sciodaphyllum chachapoyense has been collected at three localities corresponding to a single subpopulation. Its geographical range has an EOO and an AOO of 12 $\mathrm{km}^{2}$. The species is threatened by landslides, road maintenance, and other disturbances along the road that runs through the population, which results in projected continuing decline of EOO, $\mathrm{AOO}$, quality of habitat, number of locations, and number of mature individuals. With regard to the primary threat of road-associated disturbance, $S$. chachapoyense is present at three locations and can therefore be assessed as Endangered [EN B1ab(i,ii,iii,iv,v)+2ab(i,ii,iii,iv,v)] using the IUCN Red List Categories and Criteria (IUCN, 2012; IUCN Standards and Petitions Committee, 2019).

\begin{abstract}
Additional specimens examined. PERU. Amazonas: Chachapoyas Province, along road from Leymebamba to Balsas, km 410-409, 06 $43^{\prime} 16.26^{\prime \prime} \mathrm{S}, 77^{\circ} 50^{\prime} 42.22^{\prime \prime} \mathrm{W}, 2974 \mathrm{~m}, 10$ Oct 2016 [b, fl], Rodrigues-Vaz 147 (MO, NY, USM); ibid. loc., 2975 m, 10 Oct 2016 [fl, fr], Rodrigues-Vaz 148 (MO, NY [2 sheets], USM); ibid. loc., 2976 m, 10 Oct 2016 [b], Rodrigues-Vaz 149 (MO, NY [2 sheets], USM); ibid. loc., km 409 408, 06 $42^{\prime} 41.33^{\prime}$ 'S, 7750'45.85”'W, 3043 m, 10 Oct 2016 [fr], Rodrigues-Vaz 150 (MO, NY, USM); ibid. loc., km 411 416, [0642'53”S, 7751'16”W], 2700-2950 m, 21 Feb 1984 [fr], Smith 6109 (MO, USM); middle eastern Calla-Calla slopes, near km 411-416 of Leymebamba-Balsas road, [06² $42^{\prime} 53^{\prime \prime}$ S, 7751'16”W], 3100-3250 m, 11 Jul 1962 [fr], Wurdack 1336 (F [2 sheets], NY [2 sheets], USM).
\end{abstract}

Notes.-Sciodaphyllum chachapoyense and S. mathewsii occur in similar habitats (i.e., dwarf forests), but $S$. chachapoyense is found at elevations of ca. 2700 to $3250 \mathrm{~m}$, whereas $S$. mathewsii is found at lower elevations of ca. 1980 to $2500 \mathrm{~m}$.

Sciodaphyllum rufilanceolatum RodriguesVaz, G. M. Plunkett, \& Lowry, sp. nov. Type: Ecuador, Carchi: Cantón Espejo, El Gualtal, Cerro Golondrinas hembra, bosque muy húmedo montano bajo, [00 $51^{\prime} \mathrm{N}, 78^{\circ} 08^{\prime} \mathrm{W}$ ], $2800 \mathrm{~m}, 21$ Aug 1994 [fr], Palacios 12,491 (holotype, QCNE $\left[\begin{array}{lllll}9 & 9 & 2 & 8 & 5\end{array}\right]$ ! ; $\quad$ i s o t y p e, M O [MO04799627]!). $\quad$ (Fig. 5)

Diagnosis: Among Sciodaphyllum species with ferruginous indumentum, $S$. rufilanceolatum most closely resembles S. ferrugineum (Willd. ex Schult.) Decne. \& Planch. in being a hemi-epiphyte with tomentose to villose indument covering all parts of the plant except for the adaxial surface of the leaves, which is glabrescent when mature, but differs in having narrowly lanceolate to oblong leaflets (vs. broadly oblong to elliptic in S. ferrugineum).

Hemi-epiphytic, liana-like, branched treelet, 4-5 $\mathrm{m}$ tall. Leaves palmately compound, spirally arranged, 33.1-58.4 cm long; stipulate ligule chartaceous, ovate, 7.4-9.6 × 3-5.6 cm, clasping the stem, drying black, covered with tannish-white villous indument comprising unbranched trichomes, margin entire, sometimes scarious and drying grayish-white, up to $1 \mathrm{~mm}$ wide; petiole $18.9-26.5 \mathrm{~cm}$ long, 4.5-7.8 mm diam., covered with ferruginous villose indument comprising unbranched trichomes; leaflets 8-10, borne in a single whorl, petiolule 1.6$3.5 \mathrm{~cm}$, blade narrowly lanceolate to oblong, olive green adaxially, brownish olive abaxially (in sicco), coriaceous, $12.6-28.4 \times 2.3-5.6 \mathrm{~cm}$, covered with ferruginous villose indument comprising unbranched trichomes when young, adaxial surface glabrescent in mature leaflets, indument persistent on abaxial surface, base attenuate to obtuse, margin entire, revolute, apex caudate; venation pinnate, primary vein prominent, slightly raised adaxially, strongly raised abaxially, secondary veins $27-42$ on each side, visible on both surfaces, raised abaxially, tertiary veins obscure adaxially, visible abaxially, collecting vein present, $2.6-4.7 \mathrm{~mm}$ from margin. Inflorescence pseudo-lateral (resulting from delayed development of an initially terminal inflorescence), paniculate, with three orders of branching, covered with ferruginous villose indument comprising unbranched trichomes, bracts caducous, triangular, 2.8-3.1 × 3.2-4.6 mm, scar thin, crescent-shaped; primary axis $2.5 \mathrm{~cm}$ long; secondary axes $3-5,34.9-37.2 \mathrm{~cm}$ long, ultimate units heads, spherical to ellipsoid, covered with tannish-white villose indument comprising unbranched trichomes, $0.7-1.2 \mathrm{~cm}$ diam. in bud, expanding to $1.8-2.5 \mathrm{~cm}$ diam. in fruit, sessile in bud, pedunculate in flower and fruit, peduncle 3.4 $6.2 \mathrm{~mm}$ long, 1.9-3.3 mm diam. Flowers hermaphroditic, 17-39 per head, closely appressed to one another; calyx a barely visible low, undulate crest with obscure lobes, at most $0.1 \mathrm{~mm}$ high, 2.3$5.4 \mathrm{~mm}$ wide; corolla calyptrate, hemispherical, 


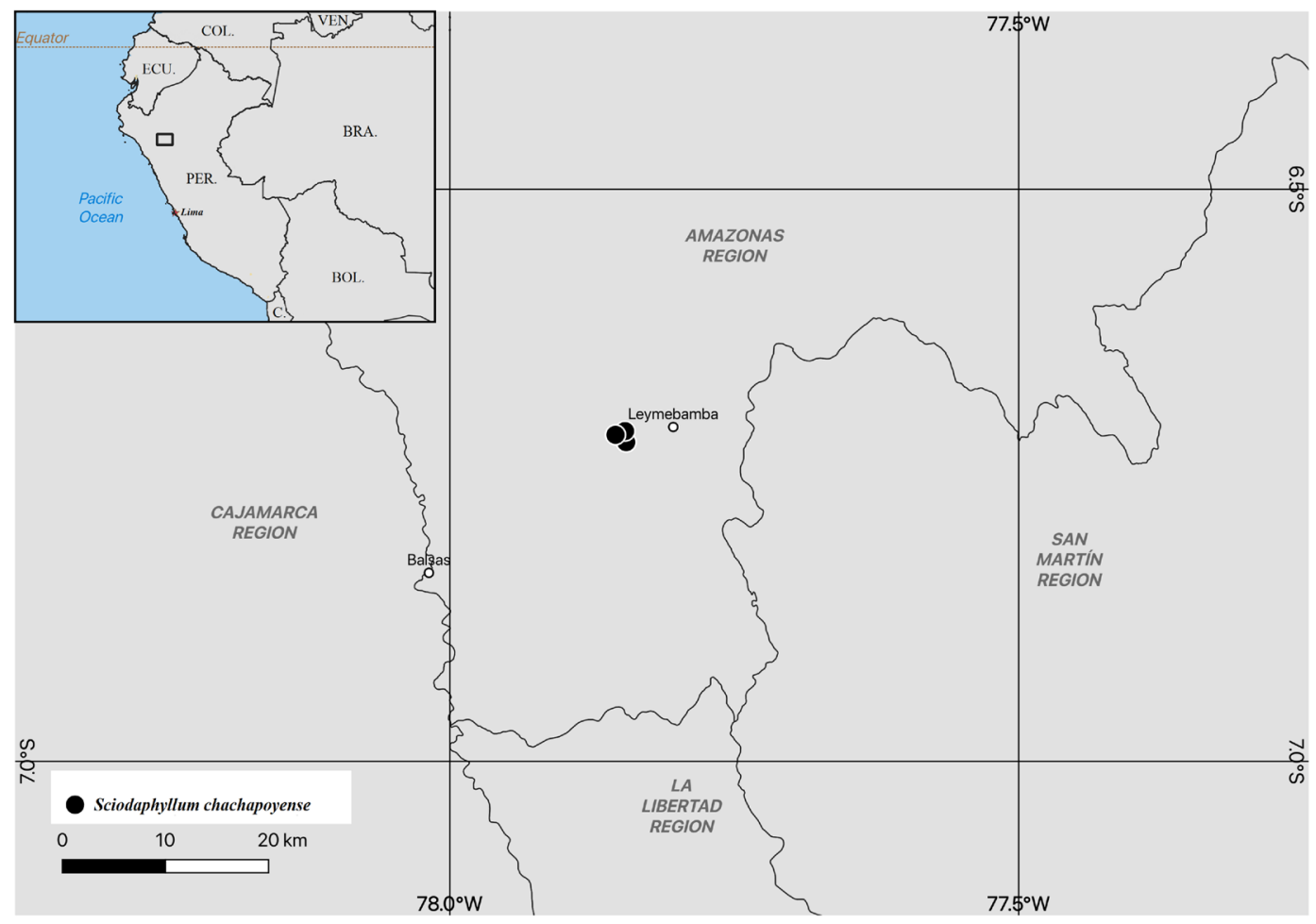

Fig. 4. Geographic distribution of Sciodaphyllum chachapoyense.

petals $5,1.7-2.4 \times 2.6-2.9 \mathrm{~mm}$; stamens 5 , in a single series, filaments $2.9-3.8 \mathrm{~mm}$ long at pollen presentation, anthers drying ferruginous to black, 0.9-1.2 mm long; ovary 5-carpellate, drying ferruginous to tan; styles 5, forming a column with a bulbous base, appressed before receptivity, spreading at maturity, drying black, $2.5-3.1 \mathrm{~mm}$ long, united for ca. two thirds of their length. Fruits fleshy, obpyramidal, transversely square or pentagonal, closely appressed to one another, 5.8-8.6 × 4.1$5.3 \mathrm{~mm}$, base truncate to conical, with 5 ribs when dry (as many as the carpels).

Distribution and habitat.-Sciodaphyllum rufilanceolatum occurs in primary montane and dwarf forests, and has been collected at four localities in Carchi Province, Ecuador, above Maldonado, near the border with Colombia (Cantón Tulcán) and in the Cerro Golondrinas near Hualchán (Cantón Espejo), at elevations of ca. 2000-2750 m. Similar suitable habitat is also found in adjacent Colombia, in the southern part of Nariño Department, but no material from this area have been seen (Fig. 6).

Etymology.-The epithet chosen for this species reflects its two principal diagnostic characters, lanceolate leaflets covered with red trichomes.

Conservation status. - Sciodaphyllum rufilanceolatum has been collected at four localities corresponding to three subpopulations. Its geographic range has an EOO of $25.5 \mathrm{~km}^{2}$ and an AOO of $20 \mathrm{~km}^{2}$. The species is present in one protected area, the Bosque Protector Cerro Golondrinas, but outside this area it is threatened by forest clearing for road construction, which results in projected continuing decline of EOO, $\mathrm{AOO}$, quality of habitat, number of locations and subpopulations, and number of mature individuals. With regard to the primary threat of forest clearing, S. rufilanceolatum is present at four locations and can therefore be assessed as Endangered [EN B 1 ab(i,ii,iii,iv, v $)+2 a b$ (i,ii,iii,iv,v)] using the IUCN Red List Categories and Criteria (IUCN, 2012; IUCN Standards and Petitions Committee, 2019).

Additional specimens examined. ECUADOR.

Carchi. Cerro Golondrinas area, access via Chamorro property above El Carmen, which is above Hualchán, flat hilltop before steep ridge crest approach to peak, $\left[00^{\circ} 50^{\prime} \mathrm{N}\right.$, 
[VOL
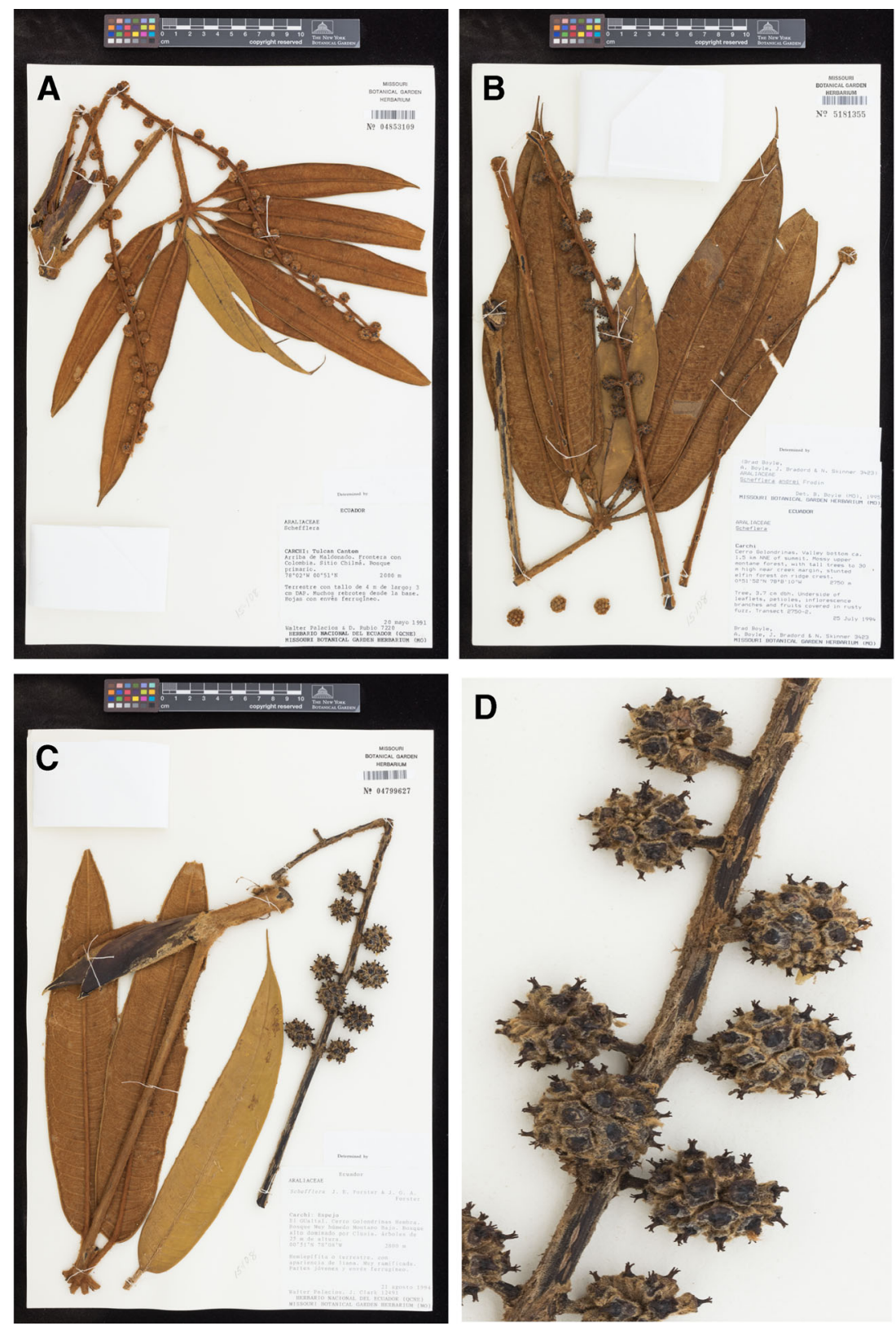

Fig. 5. Sciodaphyllum rufilanceolatum. A. Specimen in bud, Palacios 7220 [MO04853109]. B. Specimen in flower, Boyle 3423 [MO05181355]. C. Specimen in fruit, Palacios 12,491 [MO04799627]. D. Close-up of fruits of Palacios 12,491 [MO04799627].

$78^{\circ} 12^{\prime} \mathrm{W}$ ], 2690 m, 24 Jul 1993 [b, fr], Boyle 2344 (AAU, MO); Cerro Golondrinas, valley bottom ca. $1 \mathrm{~km}$ NNE of summit, $00^{\circ} 51^{\prime} 38^{\prime \prime} \mathrm{N}, 78^{\circ} 08^{\prime} 14^{\prime \prime} \mathrm{W}, 2740 \mathrm{~m}, 20 \mathrm{Jul} 1994$ [st], Boyle 3340 (AAU); Cerro Golondrinas, valley bottom ca. $1.5 \mathrm{~km} \mathrm{NNE}$ of summit, $00^{\circ} 51^{\prime} 52^{\prime} \mathrm{N}^{\circ}, 78^{\circ} 08^{\prime} 10^{\prime} \mathrm{W}, 2750$ m, 25 Jul 1994 [b, fl], Boyle 3423 (AAU, QCNE, MO); Tulcán Cantón, Arriba Maldonado, frontera con Colombia, sitio Chilmá, [0051'N, 7802’W], 2000 m, 20 May 1991 [b], Palacios 7220 (QCNE, MO). 


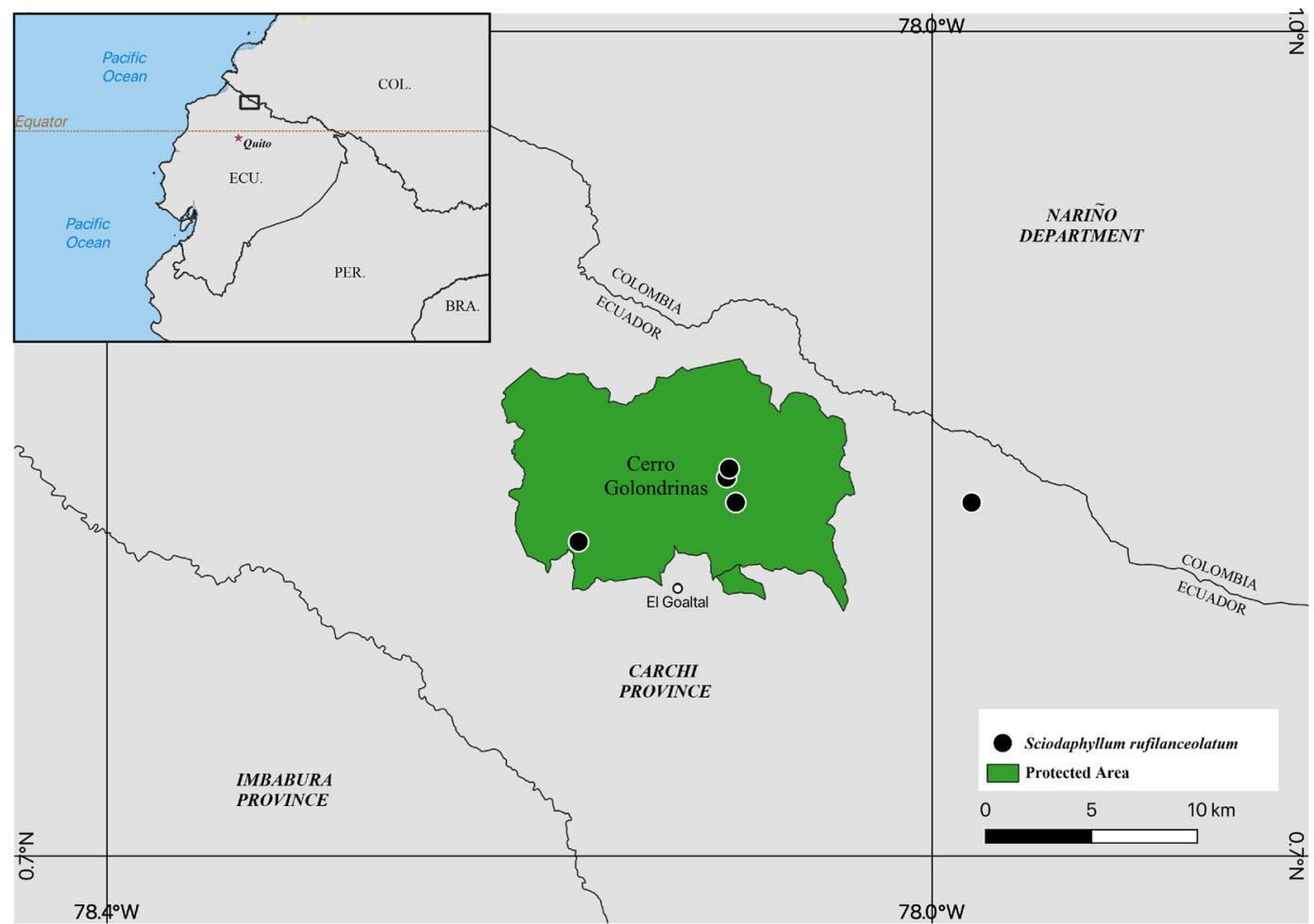

FIG. 6. Geographic distribution of Sciodaphyllum rufilanceolatum.

\section{Acknowledgements}

The authors thank the following colleagues for help in the field, Alex Rosillo and Fernanda Samaniego in Ecuador, and Marco Cueva, Elluz Huamán Melo and César Augusto Rojas Tello in Peru. We are also grateful to the following people for help obtaining permits: David Neill and Katya Romoleroux in Ecuador, and Asunción Cano Echevarría in Peru. We thank Pedro Fiaschi and Marcela Mora for very helpful comments on an earlier version of the manuscript. The curators of the following herbaria kindly provide specimens on loan and/or access to their collections: CAUP, COL, CPUN, CUVC, CUZ, ECUAMZ, F, FMB, HOXA, HUA, ICESI, JAUM, K, LOJA, MEDEL, MO, MOL, NY, PSO, QCA, QCNE, VALLE, and USM. This work was conducted as part of the first author's doctoral research, which was supported by the Annette Kade Charitable Foundation as well as NYBG's Cullman Program for Molecular Systematics. Support was also provided by grants from the U.S. National Science Foundation (1556139 to GMP and 1556327 to PPL).

\section{Literature cited}

Fiaschi, P. \& G. M. Plunkett. 2011. Monophyly and phylogenetic relationships of Neotropical Schefflera (Araliaceae) based on plastid and nuclear markers. Systematic Botany 36: 806-817.

Fiaschi, P., P. P. Lowry II \& G. M. Plunkett. 2020. Studies in Neotropical Araliaceae. III. Resurrection of the New World genus Didymopanax Decne. \& Planch., previously included in Schefflera J.R. Forst. \& G. Forst. (Araliaceae). Brittonia 72: 16-22 (https://doi.org/10.1007/s12228-01909604-w).

Frodin, D. G. 1995. Neotropical montane Araliaceae: an overview. Pp. 421-431, In: S. P. Churchill, H. Balslev, E. Forero \& J. L. Luteyn (eds), Biodiversity and Conservation of Neotropical Montane Forests. New York Botanical Garden, Bronx.

Frodin, D. G. \& R. Govaerts. 2003 (publ. 2004). World Checklist and Bibliography of Araliaceae. Royal Botanic Gardens, Kew.

Frodin, D. G., P. P. Lowry II \& G. M. Plunkett. 2010. Schefflera (Araliaceae): taxonomic history, overview and progress. Plant Diversity and Evolution 128: 561-595.

IUCN. 2012. IUCN Red List Categories and Criteria, Version 3.1, Second edition. IUCN, Gland, Switzerland and Cambridge, UK. 
IUCN Standards and Petitions Committee. 2019. Guidelines for using the IUCN Red List Categories and Criteria, Version 14. Downloadable from: http://www.iucnredlist. org/documents/RedListGuidelines.pdf.

Lowry, P. P., II, G. M. Plunkett, M. M. Mora, A. Cano, P. Fiaschi, D. G. Frodin, A. Idárraga-Piedrahíta, J. Jiménez-Montoya, J. M. Mendoza F., D. A. Neill, O. Rivera-Diaz \& C. Rodrigues-Vaz. 2019a. Studies in Neotropical Araliaceae. I. Resurrection of the genus Sciodaphyllum P. Browne to accommodate most New World species previously included in Schefflera J. R. Forst. \& G. Forst. Brittonia 72: 1-15 (https://doi.org/10.1007/ s12228-019-09593-w).

Lowry, P. P., II, G. M. Plunkett \& D. A. Neill. 2019b. Studies in Neotropical Araliaceae. II. Resurrection of the Neotropical genus Crepinella Marchal for a clade of New World species previously included in Schefflera J.R. Forst \& G. Forst. (Araliaceae). Novon 27: 253-261 (https://doi. org/10.3417/2019510).

Mora, M. M., P. P. Lowry \& G. M. Plunkett. 2020a. Studies in Neotropical Araliaceae. IV. Three new species of Sciodaphyllum P. Browne from the eastern Andes of Central Peru. Novon 28: 75-84 (https://doi.org/10.3417/2020410).

Mora, M. M., P. P. Lowry II, G. M. Plunkett, A. IdárragaPiedrahíta, J. Jiménez-Montoya \& P. H. Raven. 2020 b. Studies in Neotropical Araliaceae. V. Sciodaphyllum zarucchii (Araliaceae), a new species from Antioquia, Colombia, honoring James L. Zarucchii (1952-2019). Novon 28: 94-99 (https://doi.org/10.3417/2020540).

Plunkett, G. M., G. T. Chandler, P. P. Lowry II, S. M. Pinney \& T. S. Sprenkle. 2004a. Recent advances in understanding Apiales and a revised classification. South African Journal of Botany 70: 371-381.

Plunkett, G. M., J. Wen \& P. P. Lowry II. 2004b. Infrafamilial classifications and characters in Araliaceae: Insights from the phylogenetic analysis of nuclear (ITS) and plastid (trnL-trnF) sequence data. Plant Systematics and Evolution 245: 1-39.

Plunkett, G. M., P. P. Lowry II, D. G. Frodin \& J. Wen. 2005. Phylogeny and geography of Schefflera: pervasive polyphyly in the largest genus of Araliaceae. Annals of the Missouri Botanical Garden 92: 202-224.

Plunkett, G. M., J. Wen, P. P. Lowry II, M. J. Henwood, P. Fiaschi \& A. D. Mitchell. 2018 [publ. 2019]. Araliaceae. In: J. W. Kadereit and V. Bittrich (eds.), The Families and Genera of Vascular Plants, Vol. 15. Springer-Verlag, Berlin.

Plunkett, G. M., P. P. Lowry II, P. Fiaschi, D. G. Frodin \& A. N. Nicolas. 2019. Phylogenetic and geographic relationships among and within the Neotropical and Asian Clades of Schefflera (Araliaceae). Taxon 68: 1278-1313 (https://doi.org/10.1002/tax.12177). 